\title{
Switchgrass Biofuel Production on Reclaimed Surface Mines: I. Soil Quality and Dry Matter Yield
}

\author{
Carol Brown $^{1}$ - Thomas Griggs ${ }^{1} \cdot$ Travis Keene $^{2}$ • \\ Mike Marra $^{3}$ • Jeff Skousen ${ }^{1}$ (D) \\ Published online: 15 July 2015 \\ (C) The Author(s) 2015. This article is published with open access at Springerlink.com
}

\begin{abstract}
Growing food crops for biofuel on productive agricultural lands may become less viable as requirements to feed a growing human population increase. This has increased interest in growing cellulosic biofuel feedstocks on marginal lands. Switchgrass (Panicum virgatum L.), a warm-season perennial, is a viable bioenergy crop candidate because it produces high yields on marginal lands under low fertility conditions. In other studies, switchgrass dry matter (DM) yields on marginal croplands varied from 5.0 to $10.0 \mathrm{Mg} \mathrm{ha}^{-1}$ annually. West Virginia contains immense areas of reclaimed surface mined lands that could support a switchgrass-based biofuel industry, but yield data on these lands are lacking. Field experiments were established in 2008 to determine yields of three switchgrass cultivars on two West Virginia mine sites. One site reclaimed with topsoil and municipal sludge produced biomass yields of 19.0 Mg DM ha ${ }^{-1}$ for Cave-inRock switchgrass after the sixth year, almost double the varieties Shawnee and Carthage, at 10.0 and $5.7 \mathrm{Mg} \mathrm{ha}^{-1}$, respectively. Switchgrass yields on another site with no topsoil were 1.0 $\mathrm{Mg} \mathrm{ha}^{-1}$ after the sixth year, with little variation among cultivars. A second experiment was conducted at two other mine sites with a layer of topsoil over gray overburden. Cavein-Rock was seeded with fertilizer applications of 0,34 , and $68 \mathrm{~kg} \mathrm{~N}-\mathrm{P}_{2} \mathrm{O}_{5}-\mathrm{K}_{2} \mathrm{O}$ ha $^{-1}$. After the third year, the no fertilizer treatment averaged biomass yields of $0.3 \mathrm{Mg} \mathrm{ha}^{-1}$, while responses to the other two rates averaged 1.1 and $2.0 \mathrm{Mg} \mathrm{ha}^{-1}$,
\end{abstract}

Jeff Skousen

jskousen@wvu.edu

1 Division of Plant and Soil Sciences, West Virginia University, Morgantown, WV 26506-6108, USA

2 Mycogen Seeds, Lancaster, PA 17601, USA

3 US Army Corps of Engineers, San Antonio, TX 78258, USA respectively. Fertilization significantly increased yields on reclaimed mine soils. Where mine soil fertility was good, yields were similar to those reported on agricultural soils in the Northeastern USA.

Keywords Biomass $\cdot$ Carthage $\cdot$ Cave-in-Rock $\cdot$ Harvest management $\cdot$ Revegetation $\cdot$ Shawnee $\cdot$ Switchgrass fertilization
Abbreviations
ANOVA Analysis of variance
DM Dry matter
EC Electrical conductivity
WV West Virginia

\section{Introduction}

Switchgrass was chosen as a "model" bioenergy crop because of its ability to grow at commercial scales as a potentially profitable agricultural system [30]. Initially, the main attraction to switchgrass as a bioenergy crop was its ability to grow in many different soil types and climates throughout the USA [15]. As a warm-season (C4) species, it can grow in warmer and drier climates than cool-season species. This grass is known as a bunchgrass, but it has short rhizomes which allows it to form a sod over time [15]. It is a long-shooted species and can grow up to $3 \mathrm{~m}$ in height [32]. Cultivars are classified into lowland and upland phenotypic groups, with both groups growing well throughout the switchgrass adaptation zone [33]. Lowland ecotypes tend to be more productive [5, 31], but this advantage decreases with increasing latitude [4]. The ability to grow with low or little fertilizer inputs and less pesticide application provides economic and environmental 
advantages over annual crops that require annual seeding and fertilization [30], and that may provide less winter cover for soil and water conservation. Switchgrass can be harvested using standard agricultural haying equipment so producers can switch readily from traditional haying systems to bioenergy crop production [15].

Research has shown that switchgrass grown in the Midwestern USA can produce high yields when managed as a biofeedstock. Switchgrass grown in Nebraska, North Dakota, and South Dakota had biomass yields ranging from 5.2 to $11.2 \mathrm{Mg} \mathrm{ha}^{-1}$ averaged over the third to fifth harvest years [17]. Fike et al. [5] showed yields of $14.2 \mathrm{Mg} \mathrm{ha}^{-1}$ for 10-year-old switchgrass stands averaged over treatments and sites within the upper Southeastern USA. Averaged over four cultivars and two management treatments, switchgrass planted in West Virginia yielded approximately $13.8 \mathrm{Mg}$ $\mathrm{ha}^{-1}$, while two sites in Virginia averaged $16.6 \mathrm{Mg} \mathrm{ha}^{-1}$ annual production [5]. Three cultivars grown in Pennsylvania and harvested in the fall had an average yield of $7.9 \mathrm{Mg}$ $\mathrm{ha}^{-1}[1]$. In Iowa, 20 switchgrass cultivars yielded an average of $9.0 \mathrm{Mg} \mathrm{ha}{ }^{-1}$ over a period of 5 years [10].

Growing switchgrass on reclaimed surface mines in Eastern USA could provide an alternative to growing biofeedstocks on agricultural lands. Surface mining for coal is estimated to affect approximately 4.9 million ha of land across West Virginia, Kentucky, Virginia, and Tennessee [26]. The goals of reclamation for surface-mined lands are to restore the site's pre-disturbance land capability and to develop a profitable and sustainable post-mining land use for owners. A current popular post-mining land use is hay and pasture production from agricultural grasses and legumes, which are relatively inexpensive and reliable to establish and are desired by landowners because they provide income from haying and livestock grazing. This reclamation approach is also desired by coal operators because it provides quick ground cover necessary to meet revegetation regulatory requirements and to obtain release of reclamation surety bonds[22].

Although switchgrass performance has been evaluated on productive USA agricultural land, very little research has been done with switchgrass grown on reclaimed mine areas. Research on switchgrass growth on marginal land may provide evidence of potential switchgrass yields on mined lands. Marginal lands are those with low crop production potential due to inherent soil or climatic limitations or because they are located in areas that are difficult to seed or vulnerable to erosion [6]. Schmer et al. [17] measured annual average biomass yields of 5.2 to $11.1 \mathrm{Mg} \mathrm{ha}^{-1}$ of switchgrass when managed as a biomass energy crop on marginal cropland in the northern Great Plains, USA. Even greater yields on marginal lands in Oklahoma were shown by Kering et al. [8], with switchgrass producing $16.0 \mathrm{Mg} \mathrm{ha}^{-1}$ during the fifth year of production. Along newly constructed highways in West Virginia with rocky soils, switchgrass achieved good cover and soil stabilization after 2 years, although yields were not measured [21].

Optimizing $\mathrm{N}$ application to switchgrass stands has been a focus of research because $\mathrm{N}$ is often a limiting nutrient for switchgrass growth $[7,13,14,25]$. Determining economically optimum $\mathrm{N}$ application rates will help switchgrass producers maximize profits with high yields while reducing fertilizer and environmental costs. Unfortunately, there is no consensus on the amount of nutrients, particularly $\mathrm{N}$, to apply to a field for switchgrass growth $[8,16]$ because the amount varies with soil type and location [7]. The amount of $\mathrm{N}$ required by switchgrass is a function of the desired yield, $\mathrm{N}$ concentration of the biomass, potential productivity of the site, soil nutrient supply, and management practices [27]. To maintain productive stands under specific harvest systems and soil/site conditions, $\mathrm{N}$ additions may be needed at periodic intervals.

Switchgrass is known to use $\mathrm{N}$ efficiently because it is a $\mathrm{C} 4$ grass and upon senescence at the end of the season and during drought, it transports $\mathrm{N}$ from its shoots to roots and rhizomes [16]. Cutting switchgrass too low, which affects carbohydrate storage, and also harvesting two or three times per year will increase the amount of $\mathrm{N}$ needed by the plant [16]. Owens et al. [14] showed that switchgrass growth responds better to fertilization when initial soil $\mathrm{N}$ is low. Switchgrass $\mathrm{N}$ recovery varied between 10 and $30 \%$ [14, 24].

Vogel et al. [27] reported maximum yields of the upland cultivar Cave-in-Rock at $120 \mathrm{~kg} \mathrm{~N} \mathrm{ha}^{-1}$ in Nebraska tests, even though higher rates of fertilizer were applied (which included up to $300 \mathrm{~kg} \mathrm{~N} \mathrm{ha}^{-1}$ in their trials). Another study in Nebraska with Sunburst, also an upland variety, showed that maximum yields were reached with an $\mathrm{N}$ rate of $56 \mathrm{~kg}$ $\mathrm{ha}^{-1}$ in a test that included $112 \mathrm{~kg} \mathrm{~N}^{-1}$ [14]. The critical N rate to reach maximum yield for three different harvests in Illinois ranged from 50 to $165 \mathrm{~kg} \mathrm{~N}$ ha $^{-1}$ [2]. Hong et al. [7] reported a wide yield response to $\mathrm{N}$ fertilization across their study from New York to Oklahoma, with location and year having the greatest impacts on yield. All of these reports support the idea that supplemental $\mathrm{N}$ requirement is site-specific.

Economically viable switchgrass yields may be achievable with little or no fertilizer input. Without fertilization, one study in Georgia showed $8.6 \mathrm{Mg} \mathrm{ha}^{-1}$ of biomass production averaged over the first 4 years of switchgrass growth [9]. Kering et al. [8] showed only an $18 \%$ increase in Alamo production with an $\mathrm{N}$ fertilizer rate of $135 \mathrm{~kg} \mathrm{~N} \mathrm{ha}^{-1}$ and a potassium (K) rate of $68 \mathrm{~kg}$ $\mathrm{K}_{2} \mathrm{O} \mathrm{ha}^{-1}$ as compared to the no fertilizer control. This indicates that switchgrass grown on marginal lands may benefit from the addition of $\mathrm{K}$ along with $\mathrm{N}$. Switchgrass can grow without fertilizer inputs, but it clearly responds positively to fertilizer [12].

Many of these cited studies were conducted in agricultural soils with residual soil $\mathrm{N}$ and moderate organic matter levels, and such results might not apply to mine soils which typically have very low residual $\mathrm{N}$ amounts and little soil organic matter [3]. Adding fertilizer to mine soils is important because low $\mathrm{N}$ 
concentration in mine soils is most frequently the growthlimiting nutrient for plants [3]. It was shown by Shrestha and Lal [19] that a significant amount of total $\mathrm{N}$ is lost during mining activities and in some cases no topsoil is replaced as a growth medium, which contains a large supply of nutrients in organic matter. For soil depths of $0-15 \mathrm{~cm}$, unmined sites had total soil $\mathrm{N}$ contents ranging from 1.10 to $2.96 \mathrm{~g} \mathrm{~kg}^{-1}$ while mine soils had total soil $\mathrm{N}$ concentrations ranging from 0.54 to $1.10 \mathrm{~g} \mathrm{~kg}^{-1}$. The latter values are much lower than the total soil $\mathrm{N}$ found in unmined areas used for switchgrass growth studies in South Dakota, New York, Oklahoma, and Virginia, which averaged $1.93 \mathrm{~g} \mathrm{~kg}^{-1}$ within the top $15 \mathrm{~cm}$ [14]. This study showed that $\mathrm{N}$ use efficiency for switchgrass was highest in Virginia soils, which had the lowest total soil $\mathrm{N}$ concentrations of $0.84 \mathrm{~g} \mathrm{~kg}^{-1}$. This further supports that switchgrass will respond well to fertilizer inputs on mine soils or soils with low $\mathrm{N}$ content.

Careful fertilizer management will likely reduce the economic investment and prevent pollution of the surrounding environment with nutrients not utilized by switchgrass. Nitrogen that is leached from the soil can cause contamination of groundwater and eutrophication of water systems. To meet the regulatory ground cover standards on surface mines, the best establishment method for switchgrass on mine soils should be determined. Therefore, to reduce economic investment and prevent pollution, evaluating the optimum rate of fertilizer applied to mine soils seeded with switchgrass was one of the aims of this study.

To determine switchgrass growth on reclaimed surface mines, we conducted field-scale experiments and measured biomass yields for switchgrass cultivars in West Virginia. Our objective in experiment 1 was to determine the effect of mine soil quality on the yields of three switchgrass cultivars on two sites. We also determined the effect of N-P-K fertilizer on switchgrass yield on newly reclaimed, coarse-textured mine soils with no topsoil.

The objective of experiment 2 was to determine the best establishment methods and fertilizer rate for switchgrass growth on two reclaimed surface mines in West Virginia that simulated common reclamation practices in the area with topsoiling. Cave-in-Rock was seeded immediately after the sites were backfilled and topsoiled. Three rates of mulch and fertilizer were applied at switchgrass seeding.

\section{Materials and Methods}

\section{Site Locations and Management}

\section{Experiment 1}

This experiment was established in 2008 on two reclaimed surface mine areas in West Virginia. The first site,
Hampshire $\left(39.4^{\circ} \mathrm{N}, 79.1^{\circ} \mathrm{W}\right)$, is located on a small contour mine in Mineral County, which stopped operations in 1998. The 30-year average annual precipitation at the site is $110 \mathrm{~cm}$, average temperature is $9{ }^{\circ} \mathrm{C}$, and elevation is $680 \mathrm{~m}$. This site utilized smaller mining equipment and trucks, and in 1996 during reclamation, $0.3 \mathrm{~m}$ of topsoil was placed over regraded overburden. In 1998, 2003, and 2008, lime-treated sludge was applied at a rate of $225 \mathrm{dry} \mathrm{Mg} \mathrm{ha}^{-1}$. The sludge consisted of municipal sewage waste from the Westernport, MD, municipal wastewater treatment facility and paper mill pulp from the nearby NewPage paper mill. Because of the application of topsoil and sludge, the site had favorable soil properties which greatly enhanced revegetation potential. This site was selected for planting because it represented very favorable reclamation conditions available for establishing switchgrass.

The second site, Hobet $\left(38.1^{\circ} \mathrm{N}, 81.6^{\circ} \mathrm{W}\right)$, is located on a large mountaintop surface mine in Boone and Kanawha counties (near Madison, WV) operated by Hobet Mining Company. Average 30-year annual precipitation at this site is $115 \mathrm{~cm}$, average temperature is $13{ }^{\circ} \mathrm{C}$, and elevation is $380 \mathrm{~m}$. This mine utilizes a large dragline for overburden removal in order to reach the coal seam. Overburden was dumped with the dragline bucket and regraded to approximate original contour by large bulldozers after mining. The compacted overburden was covered with $1 \mathrm{~m}$ of crushed, unweathered rock material. The heavily compacted overburden material placed as soil was broken up with a large offset disk before planting. This reclamation strategy was selected to simulate unfavorable reclamation conditions where no topsoil was applied and soil fertility was poor.

At each site, nine 0.4-ha plots were laid out in 2008 in a completely randomized design with three replications. Three cultivars of switchgrass (Cave-in-Rock, Carthage, and Shawnee) were randomly assigned to plots and broadcastseeded at a rate of $11.2 \mathrm{~kg}$ pure live seed (PLS) ha ${ }^{-1}$ on 8 10 June 2008 [see 11]. Poor growth at Hobet led to fertilizing subplots within each plot in 2009 and 2013. These subplots were randomly chosen and fertilized with $224 \mathrm{~kg} \mathrm{ha}^{-1}$ of 1919-19 $\left(\mathrm{N}^{-} \mathrm{P}_{2} \mathrm{O}_{5}-\mathrm{K}_{2} \mathrm{O}\right)$ to obtain $43 \mathrm{~kg} \mathrm{ha}^{-1}$ of $\mathrm{N}, \mathrm{P}_{2} \mathrm{O}_{5}$, and $\mathrm{K}_{2} \mathrm{O}$.

\section{Experiment 2}

Two newly reclaimed sites in West Virginia were chosen to determine switchgrass establishment with two levels of $\mathrm{N}$ $\mathrm{P}_{2} \mathrm{O}_{5}-\mathrm{K}_{2} \mathrm{O}$ fertilization and mulch at planting. The Coal Mac site $\left(37.7^{\circ} \mathrm{N}, 82.0^{\circ} \mathrm{W}\right)$ is located on a large mountaintop surface mine in Mingo, Logan, and Boone counties operated by Arch Coal, Inc. The 30 -year average annual precipitation at the site is $118 \mathrm{~cm}$, average temperature is $14{ }^{\circ} \mathrm{C}$, and elevation is 550 $\mathrm{m}$. This mining operation utilizes large draglines, shovels, and 
Table 1 Selected soil chemical and physical properties at Hampshire and Hobet averaged over 2010-2013, and at Black Castle and Coal Mac averaged over 2011-2013

\begin{tabular}{lllll}
\hline Property & Hampshire & Hobet & Black Castle & Coal Mac \\
\hline $\mathrm{pH}$ & $7.3 \mathrm{a}^{\mathrm{a}}$ & $7.7 \mathrm{~b}$ & $5.8 \mathrm{x}^{\mathrm{c}}$ & $6.1 \mathrm{x}$ \\
$\mathrm{EC}\left(\mu \mathrm{S} \mathrm{cm}^{-1}\right)$ & $648 \mathrm{a}$ & $140 \mathrm{~b}$ & $460 \mathrm{x}$ & $96 \mathrm{y}$ \\
\% Fines $(\%)$ & $78 \mathrm{a}$ & $57 \mathrm{~b}$ & $37 \mathrm{x}$ & $42 \mathrm{x}$ \\
\% Sand & $42 \mathrm{~b}$ & $63 \mathrm{a}$ & $51 \mathrm{x}$ & $60 \mathrm{x}$ \\
\% Silt & $47 \mathrm{a}$ & $27 \mathrm{~b}$ & $25 \mathrm{x}$ & $28 \mathrm{x}$ \\
\% Clay & $11 \mathrm{a}$ & $10 \mathrm{a}$ & $13 \mathrm{x}$ & $12 \mathrm{x}$ \\
\hline
\end{tabular}

Soil data from Hampshire and Hobet in 2010 and 2011 were previously published in Marra et al. [11]

$E C$ electrical conductivity

${ }^{a}$ Values with different letters for Hampshire and Hobet for each property are different at $p \leq 0.05$

${ }^{\mathrm{b}}$ Values with different letters for Black Castle and Coal Mac for each property are different at $p \leq 0.05$

loaders to remove overburden and coal. The experimental area was leveled and reclaimed in 2011 with 0.6 to $0.9 \mathrm{~m}$ of topsoil and weathered sandstone mixture that was placed over gray sandstone overburden. The Black Castle site $\left(38.1^{\circ} \mathrm{N}, 81.7^{\circ} \mathrm{W}\right)$ is located in Boone County on a large mountaintop surface mine and owned by Alpha Natural Resources. Long-term average annual precipitation at the site is $115 \mathrm{~cm}$, average temperature is $13{ }^{\circ} \mathrm{C}$, and elevation is $540 \mathrm{~m}$. Reclamation was done in 2011 by leveling unweathered overburden and covering it with 0.2 to $0.3 \mathrm{~m}$ of topsoil mixed with crushed weathered rock.
Plots at each site were established in a randomized complete block design with five replications. Each block was 0.4 ha and divided into four plots to which four treatments were randomly assigned. Cave-in-Rock was broadcast-seeded at $11.2 \mathrm{~kg}$ PLS ha ${ }^{-1}$ on 5 June 2009. Treatments applied at planting were as follows:

1. No fertilizer, light mulch: Control; $1.5 \mathrm{Mg} \mathrm{ha}^{-1}$ application of hydromulch (dry wt)

2. Low fertilizer, light mulch: $34 \mathrm{~kg} \mathrm{~N}-\mathrm{P}_{2} \mathrm{O}_{5}-\mathrm{K}_{2} \mathrm{O}$ ha ${ }^{-1}$ and $1.5 \mathrm{Mg} \mathrm{ha}^{-1}$ application of hydromulch

3. Low fertilizer, heavy mulch: $34 \mathrm{~kg} \mathrm{~N}-\mathrm{P}_{2} \mathrm{O}_{5}-\mathrm{K}_{2} \mathrm{O} \mathrm{ha}^{-1}$ and $3.0 \mathrm{Mg} \mathrm{ha}^{-1}$ application of hydromulch

4. High fertilizer, light mulch: $68 \mathrm{~kg} \mathrm{~N}-\mathrm{P}_{2} \mathrm{O}_{5}-\mathrm{K}_{2} \mathrm{O}$ ha ${ }^{-1}$ and $1.5 \mathrm{Mg} \mathrm{ha}^{-1}$ application of hydromulch

Surface mining reclamation regulations in West Virginia require a minimum of $68 \mathrm{~kg} \mathrm{ha}^{-1}$ of $\mathrm{N}-\mathrm{P}_{2} \mathrm{O}_{5}-\mathrm{K}_{2} \mathrm{O}$ and $1.0 \mathrm{Mg} \mathrm{ha}^{-1}$ of mulch be applied during reclamation [28]. Either 340 or $680 \mathrm{~kg} \mathrm{ha}^{-1}$ of commercial 10-10-10 fertilizer was applied to plots for fertilizer-mulch treatments. Hydromulch was used instead of hay or straw mulch because hydromulch is commonly used with hydroseeding, the preferred method for revegetating surface mines in this region. Hydromulch is a paper-based product that helps to protect the soil and retain soil moisture while seeds are germinating. Our treatment rates were based on the assumptions that switchgrass needed less $\mathrm{N}$ fertilizer for establishment than standard coolseason agricultural grasses used for revegetation and that the slow establishment rate of switchgrass would require more mulch to reduce erosion.
Table 2 Values of extractable soil nutrients using Mehlich 1 solution at four sites

\begin{tabular}{lllll}
\hline Parameter & Hampshire & Hobet & Black Castle & Coal Mac \\
\hline & \multicolumn{2}{c}{ cmol charge kg $^{-1}$} & & \\
\cline { 2 - 2 } & $0.84 \mathrm{a}^{\mathrm{a}}$ & $0.73 \mathrm{a}$ & $0.86 \mathrm{x}^{\mathrm{b}}$ & $0.16 \mathrm{y}$ \\
$\mathrm{K}$ & $0.16 \mathrm{a}$ & $0.10 \mathrm{a}$ & $0.11 \mathrm{x}$ & $0.21 \mathrm{x}$ \\
$\mathrm{Na}$ & $0.04 \mathrm{a}$ & $0.01 \mathrm{a}$ & $0.05 \mathrm{x}$ & $0.05 \mathrm{x}$ \\
$\mathrm{Ca}$ & $7.74 \mathrm{a}$ & $1.20 \mathrm{~b}$ & $1.32 \mathrm{x}$ & $0.24 \mathrm{y}$ \\
& & & & \\
$\mathrm{Al}$ & $67.8 \mathrm{a}$ & $22.0 \mathrm{~b}$ & $29.7 \mathrm{x}$ & $11.0 \mathrm{y}$ \\
$\mathrm{Fe}$ & $17.4 \mathrm{a}$ & $38.8 \mathrm{a}$ & $18.6 \mathrm{x}$ & $6.2 \mathrm{y}$ \\
$\mathrm{Mn}$ & $41.3 \mathrm{a}$ & $19.0 \mathrm{a}$ & $31.1 \mathrm{x}$ & $3.03 \mathrm{y}$ \\
$\mathrm{P}$ & $5.2 \mathrm{~b}$ & $26.4 \mathrm{a}$ & $5.7 \mathrm{x}$ & $2.1 \mathrm{y}$ \\
$\mathrm{Ni}$ & $0.3 \mathrm{a}$ & $0.6 \mathrm{a}$ & $0.46 \mathrm{x}$ & $0.03 \mathrm{y}$ \\
$\mathrm{Cu}$ & $1.1 \mathrm{a}$ & $1.0 \mathrm{a}$ & $0.77 \mathrm{x}$ & $0.14 \mathrm{y}$ \\
$\mathrm{Zn}$ & $4.4 \mathrm{a}$ & $1.4 \mathrm{~b}$ & $1.1 \mathrm{x}$ & $0.13 \mathrm{y}$ \\
\hline
\end{tabular}

Hampshire and Hobet were averaged over 2010-2013, while Black Castle and Coal Mac were averaged over 2011-2013; soil data from Hampshire and Hobet in 2010 to 2011 were previously published in Marra et al. [11]

${ }^{\mathrm{a}}$ Values with different letters for Hampshire and Hobet for each property are different at $p \leq 0.05$

${ }^{\mathrm{b}}$ Values with different letters for Black Castle and Coal Mac for each property are different at $p \leq 0.05$ 


\section{Vegetation Measurement and Analysis}

Biomass samples were taken each year during the last week of September at post-anthesis stage. Six sampling points were located in each plot at Hampshire and Hobet, providing 18 subsamples of yield per cultivar-site. At Black Castle and Coal Mac, three sampling points were located in each plot of the five blocks, providing 15 subsamples of yield per treatment at each site. A $0.21-\mathrm{m}^{2}$ quadrat was placed on the ground at each randomly selected sampling point, and all switchgrass inside the quadrat was clipped to a $10-\mathrm{cm}$ stubble height. Parrish and Fike [16] suggested in a literature review that a $10-\mathrm{cm}$ stubble height resulted in better stand persistence than clipping at lower heights. Herbage from plants other than switchgrass (such as legumes and weeds) within the quadrat was discarded, which accounted for less than $1 \%$ in most samples. Samples were oven-dried to constant weight at $60{ }^{\circ} \mathrm{C}$ to determine dry matter (DM) yield, and average yields were calculated. Biomass was not removed from plots annually other than in random, non-repeating sampling areas. Biomass collected in our plots was composed of current year's growth, with less than $5 \%$ being from previous year's growth. Yield data from 2010 and 2011 (previously published in [11]) were included with 2012 and 2013 yield data to analyze over a 4-year period.

Yields in experiment 1 (Hampshire and Hobet) were analyzed using a mixed-model, repeated-measures analysis of variance (ANOVA) of the Statistical Analysis System [23] with years as repeated measures and effects of site, cultivar, year, and interactions. Sites, cultivars, and years were considered fixed effects, while plot and replication were considered random effects. No data transformations were necessary in experiment 1 because the assumptions of normal distributions for ANOVA were satisfied according to the Shapiro-Wilk normality test [18]. Statistical significance was based on a $p$ value of 0.05 . When necessary, Tukey's honestly significant difference (HSD) multiple comparison test was used to separate means among cultivars and years. When comparing yields at Hobet and Hampshire, the fertilized subplots at Hobet were removed from the model because Hampshire had not been subjected to the same treatment. Yields at Hobet were analyzed separately to see if fertilization affected yield under the same significance criterion.

Yields in experiment 2 (Black Castle and Coal Mac) were analyzed using a mixed-model, repeated-measures ANOVA [23] with years as repeated measures and effects of site, treatment, year, and interactions. Sites, treatments, and years were considered fixed effects, while blocks and replications were considered random effects. Data in experiment 2 were log-transformed to satisfy the assumptions of normal distributions for ANOVA according to the Shapiro-Wilk normality test [18]. Untransformed means are shown in the table and figure for this experiment.
Table 3 Mean switchgrass yields and significance of main effects of site, cultivar, and year

\begin{tabular}{lll}
\hline Effect & Significance & Yield $^{\mathrm{a}}$ \\
\hline & $<0.01$ & $\mathrm{Mg} \mathrm{ha}^{-1}$ \\
Site & & $8.4 \mathrm{a}^{\mathrm{a}}$ \\
Hampshire & $<0.01$ & $1.0 \mathrm{~b}$ \\
Hobet & & \\
Cultivar & & $2.8 \mathrm{c}$ \\
Carthage & & $7.0 \mathrm{a}$ \\
Cave-in-Rock & $4.3 \mathrm{~b}$ \\
Shawnee & & \\
Year & & $4.2 \mathrm{bc}$ \\
$2010^{\mathrm{b}}$ & & $3.0 \mathrm{c}$ \\
2011 & & $5.0 \mathrm{ab}$ \\
2012 & & $6.5 \mathrm{a}$ \\
2013 &
\end{tabular}

Interactions were significant for cultivar $\times$ site $(p<0.01)$ and site $\times$ year $(p<0.01)$

${ }^{\mathrm{a}}$ Data from Hampshire and Hobet in 2010 to 2011 were previously published in Marra et al. [11]

${ }^{\mathrm{b}}$ Different letters for each main effect denote difference at $p \leq 0.05 \mathrm{ac}-$ cording to ANOVA or Tukey's HSD

Statistical significance was based on a $p$ value of 0.05 , and Tukey's HSD test was used to separate means among treatments and years.

\section{Soil Sampling and Analysis}

Soil samples were collected at each sampling point as shallow shovel slices to approximately $15-\mathrm{cm}$ depth at all sites annually and analyzed for percent fines, $\mathrm{pH}$, electrical conductivity (EC), and available elements specified later. At Hampshire, two samples per plot were obtained: Three subsamples were composited from each pair of three biomass sampling points.

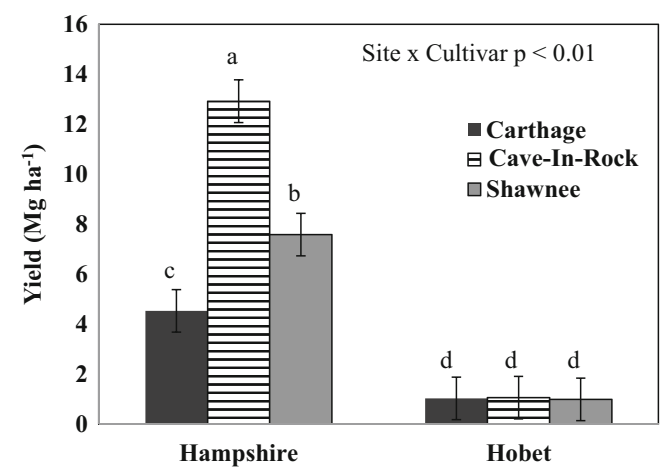

Fig. 1 Yield of switchgrass cultivars at each site averaged over years (2010-2013). Vertical bars represent standard errors. Different letters on bars denote difference at $p \leq 0.05$ according to Tukey's HSD. Yield data in 2010 to 2011 were previously published in Marra et al. (2013) 


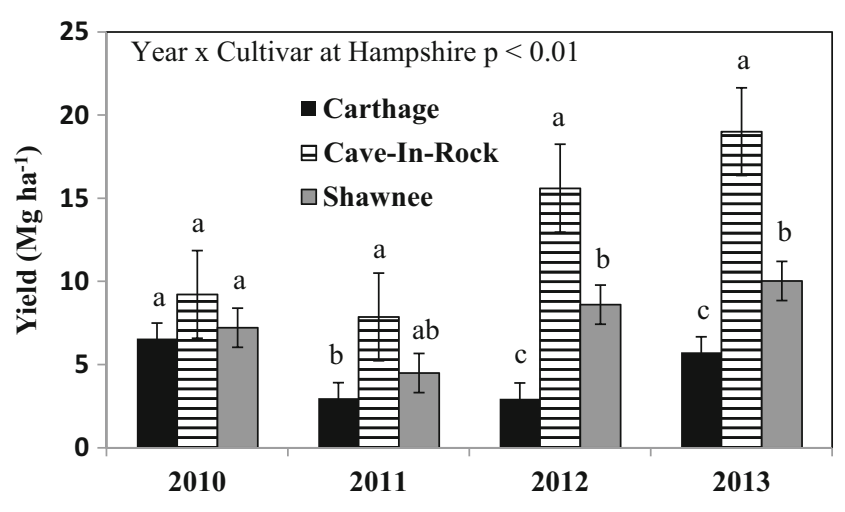

Fig. 2 Yield of switchgrass cultivars for each year at Hampshire only. Combining the data for Hampshire and Hobet showed a nearly identical figure since Hobet yields were essentially the same for all cultivars during all years. Yield data in 2010 and 2011 were previously published in Marra et al. [11]

For Hobet, three samples were composited per fertilizer treatment subplot, giving two soil samples per plot. For Black Castle and Coal Mac, soil samples were collected at biomass sampling points and composited for each treatment providing four soil samples per block, so five samples were obtained for each treatment. Soil samples were air-dried, weighed, and sieved to pass through a 2-mm sieve. Percent fines were determined by subtracting the weight of material passing through the sieve from the whole sample weight. Subsamples of the fine fraction were taken using a riffle splitter and used for soil analysis of $\mathrm{pH}, \mathrm{EC}$, and available nutrients.

For $\mathrm{pH}, 5 \mathrm{~g}$ of soil was combined with $5 \mathrm{~mL}$ of distilled deionized (DDI) water. The mixture was placed on an orbital shaker table and mixed for $15 \mathrm{~min}$ and then allowed to equilibrate for at least $1 \mathrm{~h}$. A pH meter (Seven Easy, Mettler Toledo) was used to measure $\mathrm{pH}$. Electrical conductivity was determined by combining $5 \mathrm{~g}$ of soil with $10 \mathrm{~mL}$ DDI water. The mixture was placed on an orbital shaker table and mixed for $15 \mathrm{~min}$ and then allowed to equilibrate for at least 1 h. A conductivity meter (Seven Compact S230, Mettler Toledo) was used to measure EC.
Available elements were extracted from soils with a Mehlich 1 solution [29]. For extraction, $25 \mathrm{~mL}$ of Mehlich 1 solution was added to $5 \mathrm{~g}$ of soil, mixed on an orbital shaker for $5 \mathrm{~min}$, and then allowed to equilibrate. Samples were filtered through Whatman No. 2 filter paper, and an inductively coupled plasma emission spectrometer (ICP-ES; Perkin Elmer) was used to analyze the filtrate for available $\mathrm{Al}$, $\mathrm{Fe}, \mathrm{Mn}, \mathrm{Mg}, \mathrm{Ca}, \mathrm{K}, \mathrm{P}, \mathrm{Ni}, \mathrm{Cu}$, and $\mathrm{Zn}$. Soil chemical data were analyzed using a mixed-model, repeated measures ANOVA [23] with years as repeated measures. Few differences were found across years within sites, so an average value is reported for each site. However, significant differences were found for many properties between sites. Soils data from 2010 and 2011 (previously reported in [11]) were included with values from 2012 and 2013 to calculate 4-year means.

\section{Results and Discussion}

\section{Soil Properties}

Due to the different reclamation techniques, soil properties between Hampshire and Hobet were very different (Table 1). Hampshire had more fine material and higher EC than Hobet because of topsoiling and amendments (Table 1). The topsoil and lime-treated sewage/paper sludge at Hampshire resulted in a better soil medium for plants than the unweathered overburden material used at Hobet. This material had not been given much time to weather and therefore the larger rock fragments translated into lower percent fines and presumably lower fertility and water holding capacity than Hampshire mine soils.

Only $\mathrm{Ca}, \mathrm{Al}, \mathrm{P}$, and $\mathrm{Zn}$ concentrations differed between mine soils at Hampshire and Hobet (Table 2). Due to the sludge amendments, finer texture, and lower $\mathrm{pH}$, Hampshire mine soils contained higher $\mathrm{Ca}, \mathrm{Al}$, and $\mathrm{Zn}$ than Hobet. High $\mathrm{P}$ at Hobet with no topsoil and coarse texture is commonly found on these types of mine soils. When extracted with
Fig. 3 a Yield of switchgrass at Hampshire for each year averaged across cultivar. b Yield of switchgrass at Hobet for each year averaged across cultivar. Vertical bars represent standard errors. Different letters on bars denote significant differences at $p \leq 0.05$ according to Tukey's HSD. Yield data at Hobet in 2010 to 2011 were previously published in Marra et al. [11]

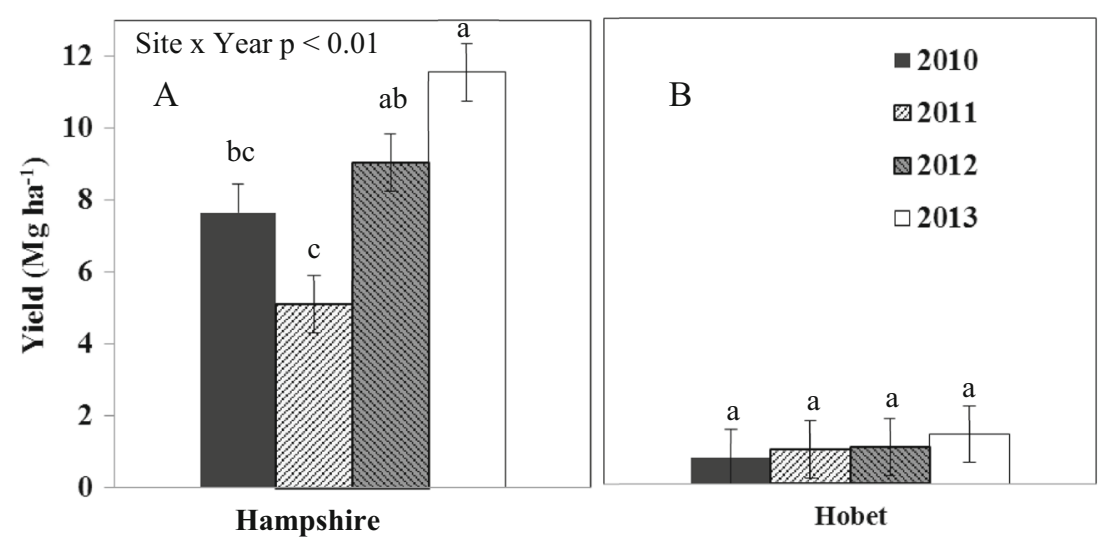


Mehlich 1, these overburden-derived mine soils often contain high levels of P, but Skousen and Emerson [20] found that the $\mathrm{P}$ is tightly bound to $\mathrm{Ca}$ minerals and unavailable to plants.

Black Castle soils had higher values for $\mathrm{Mg}$ and $\mathrm{Ca}$, as well as all the micro-nutrients we measured, than Coal Mac (Table 2). Even though less topsoil was applied at Black Castle and this material had a slightly lower $\mathrm{pH}$, it apparently was of better quality and fertility. The Black Castle EC value was four times higher than that of Coal Mac, which may indicate higher levels of nutrients and ions in solution (Table 1).

\section{Experiment 1-Switchgrass Yields at Hampshire and Hobet}

Yields of switchgrass at Hampshire were significantly higher at $8.4 \mathrm{Mg} \mathrm{ha}^{-1}$ compared to $1.0 \mathrm{Mg} \mathrm{ha}^{-1}$ at Hobet when averaged across cultivars and years (Table 3). Clearly, the more fertile mine soil at Hampshire resulted in exceptionally high yields for all three cultivars. The low yields at Hobet could be attributed to poor soil conditions and soil moisture sensitivity of switchgrass [5] since fines were $<60$ (Table 1). Hampshire also had a higher EC quantity which relates to more fertile soils (Table 1).

Yield was significantly different among cultivars (Table 3 ) and site $\times$ cultivar and year $\times$ cultivar interactions were significant. All cultivars at Hobet had poor yields $\left(1.0 \mathrm{Mg} \mathrm{ha}^{-1}\right)$ and were much lower than cultivar yields at Hampshire (Fig. 1). The highest-performing cultivar at Hampshire was Cave-in-Rock, yielding $12.9 \mathrm{Mg} \mathrm{ha}^{-1}$ averaged over years (Fig. 2). Yields of Shawnee (7.6 Mg ha ${ }^{-1}$ ) and Carthage $\left(4.5 \mathrm{Mg} \mathrm{ha}^{-1}\right)$ were lower than Cave-in-Rock, and Carthage was lower than Shawnee.

A significant site $\times$ year interaction was found (Fig. 3a, b). Hobet had similar yields across cultivars for all years and showed only a slow upward trend with time (Fig. 3b). At Hampshire, yields increased from $7.7 \mathrm{Mg} \mathrm{ha}^{-1}$ in 2010 to 11.6 $\mathrm{Mg} \mathrm{ha}^{-1}$ in 2013. It was expected that switchgrass yields would continue to increase with time, which was seen except for 2011. At Hampshire after 6 years of growth, Cave-in-Rock yielded $19.0 \mathrm{Mg} \mathrm{ha}^{-1}$, while Shawnee was $10.0 \mathrm{Mg} \mathrm{ha}^{-1}$, and Carthage $5.7 \mathrm{Mg} \mathrm{ha}^{-1}$ (Fig. 2).

Similar yields for these cultivars have been documented in this region with better soils. For example, Cave-in-Rock grown on agricultural soils in West Virginia and fertilized annually with $50 \mathrm{~kg} \mathrm{~N} \mathrm{ha}^{-1}$ had comparable yields of $15 \mathrm{Mg} \mathrm{ha}^{-1}$ [5]. Cave-in-Rock yielded $8.6 \mathrm{Mg} \mathrm{ha}^{-1}$ and Shawnee yielded $8.5 \mathrm{Mg} \mathrm{ha}^{-1}$ on agricultural soils in Pennsylvania [1]. Yields of these cultivars from plots on a research farm in Iowa were Carthage, 9.9; Cave-in-Rock, 9.3; and Shawnee, $8.8 \mathrm{Mg} \mathrm{ha}^{-1}$ [10]. These stands in Iowa also received $112 \mathrm{~kg} \mathrm{~N} \mathrm{ha}^{-1}$ as ammonium nitrate.

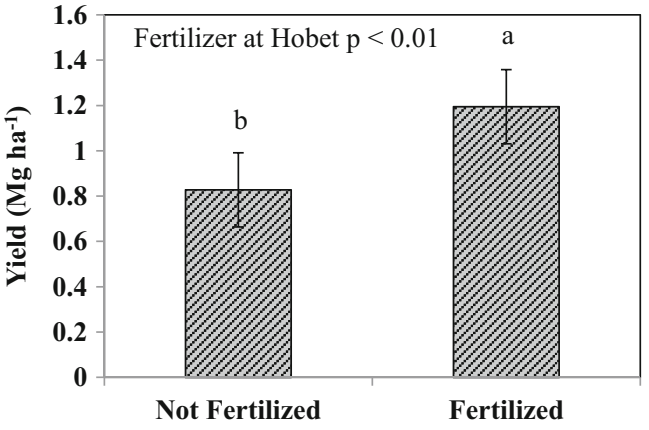

Fig. 4 Yield comparison of fertilizer treatment across cultivars and years to the harsh mine soil conditions at Hobet. Vertical bars represent standard errors

\section{Experiment 1-Comparison of Fertilization at Hobet}

To see if yields could be increased in the harsh mine soils at Hobet, $43 \mathrm{~kg} \mathrm{~N}-\mathrm{P}_{2} \mathrm{O}_{5}-\mathrm{K}_{2} \mathrm{O}$ ha $^{-1}$ was added to subplots in 2009 and 2013. Fertilizing increased switchgrass yields at Hobet (Fig. 4) to $1.2 \mathrm{Mg} \mathrm{ha}^{-1}$ compared with $0.85 \mathrm{Mg} \mathrm{ha}^{-1}$ for unfertilized plots across years and cultivars. Differences in yield may have been greater if fertilization was done annually rather than in only 2 out of 5 years. We found a year, but no cultivar effect on yields (data not shown), with a small increase in yield with time at Hobet (similar to that seen in Fig. 3b). Even with fertilization, yields were still very low at Hobet with the majority of mean values being $<1.5 \mathrm{Mg} \mathrm{ha}^{-1}$. Fertilizing does not appear to compensate for the poor mine soil conditions (coarse texture, low water-holding capacity, low organic matter) at Hobet to produce good yields. Adding topsoil and organic material, such as sewage sludge or paper mill sludge, may accelerate the transformation of soils into a suitable medium for switchgrass growth, as clearly seen at Hampshire.

Table 4 Mean switchgrass yields for main effects of site, treatment, and year at Black Castle and Coal Mac

\begin{tabular}{llc}
\hline Effect & Significance & Yield \\
\hline & & Mg ha $^{-1}$ \\
Site & 0.94 & \\
$\quad$ Black Castle & & $0.98 \mathrm{a}^{\mathrm{a}}$ \\
$\quad$ Coal Mac & $<0.01$ & $0.97 \mathrm{a}$ \\
Treatment & & $0.32 \mathrm{c}$ \\
0 fertilizer; light mulch & $1.14 \mathrm{~b}$ \\
$34 \mathrm{~kg}_{\text {fertilizer ha }}{ }^{-1}$; light mulch & & $1.12 \mathrm{~b}$ \\
$34 \mathrm{~kg}$ fertilizer ha ${ }^{-1}$; heavy mulch & & $1.95 \mathrm{a}$ \\
$68 \mathrm{~kg}$ fertilizer ha ${ }^{-1}$; light mulch & & \\
Year & $<0.01$ & $0.28 \mathrm{c}$ \\
2011 & & $0.95 \mathrm{~b}$ \\
2012 & & $2.70 \mathrm{a}$ \\
2013 & &
\end{tabular}

${ }^{\text {a }}$ Different letters for main effect yields denote difference at $p \leq 0.05$ 
Fig. 5 Yield of switchgrass for four treatments for each year averaged over the two sites. Vertical bars represent standard errors

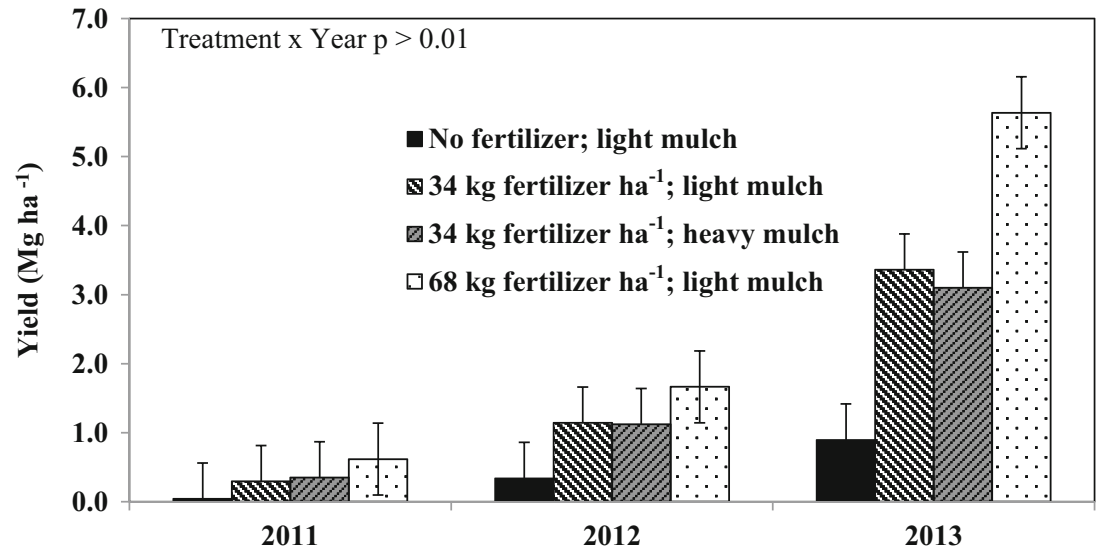

\section{Experiment 2-Comparison of Fertilizer Treatments at Black Castle and Coal Mac}

Higher soil micro- and macro-nutrient concentrations at Black Castle than at Coal Mac (Tables 1 and 2) could have supported higher switchgrass yields at Black Castle. Site yields, however, were nearly identical over 3 years (Table 4) with Black Castle and Coal Mac producing 0.98 and $0.97 \mathrm{Mg} \mathrm{ha}^{-1}$, respectively, averaged over years and treatments. Even with the differences in nutrient values, the sites were reclaimed in a similar manner with a mixture of topsoil and brown weathered sandstone, which resulted in very similar switchgrass yields (Table 4).

A significant treatment effect was found in this experiment. The treatment with no fertilizer and light mulch had the lowest yields at $0.32 \mathrm{Mg} \mathrm{ha}^{-1}$ averaged over years and sites. Plots fertilized with $34 \mathrm{~kg} \mathrm{~N}-\mathrm{P}_{2} \mathrm{O}_{5}-\mathrm{K}_{2} \mathrm{O}$ ha $^{-1}$ averaged $1.13 \mathrm{Mg}$ $\mathrm{ha}^{-1}$, while those fertilized with $68 \mathrm{~kg} \mathrm{ha}^{-1}$ yielded $1.95 \mathrm{Mg}$ $\mathrm{ha}^{-1}$. No effect on yield was found for light versus heavy hydromulch rates at $34 \mathrm{~kg} \mathrm{~N}-\mathrm{P}_{2} \mathrm{O}_{5}-\mathrm{K}_{2} \mathrm{O}$ ha $^{-1}$.

Results showed a significant treatment $\times$ year interaction (Fig. 5). Yields in 2011 were only $0.04 \mathrm{Mg} \mathrm{ha}^{-1}$ with no

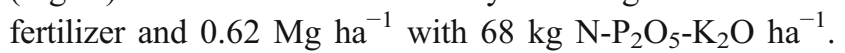
After the third growing season in 2013 , yields were $0.90 \mathrm{Mg}$ $\mathrm{ha}^{-1}$ with no fertilizer and $5.64 \mathrm{Mg} \mathrm{ha}^{-1}$ with $68 \mathrm{~kg} \mathrm{ha}^{-1}$ fertilizer. This result is consistent with reports of slow switchgrass establishment and low amounts of biomass during the first few years after planting $[5,11,16,27]$. Higher yields were apparent by 2013 , after the third growing season, and should continue to increase based on the yields at Hampshire after 6 years. On surface mine soils, fertilization was found to be essential to increase yields.

\section{Conclusions}

With the placement of a proper soil medium during reclamation and the addition of amendments, reclaimed surface mine soils produced comparable yields of switchgrass to those produced on regional agricultural soils. As shown at Hampshire, reclaiming with topsoil and organic amendments created good soil conditions for switchgrass growth, while the unweathered overburden at Hobet produced poor growing conditions and low switchgrass yields. It is clear that switchgrass would benefit from at least some topsoil or weathered overburden to provide a more suitable soil for a thicker and higher-yielding switchgrass stand. Cave-in-Rock was the highest performing cultivar at Hampshire, which indicates that it would be a better cultivar to grow in West Virginia compared to Carthage and Shawnee. Fertilization with $43 \mathrm{~kg} \mathrm{ha}^{-1}$ of $\mathrm{N}-\mathrm{P}_{2} \mathrm{O}_{5}-\mathrm{K}_{2} \mathrm{O}$ was unable to compensate for the poor mine soil conditions at Hobet, although yields were increased slightly with fertilization.

On newly reclaimed sites, fertilization was shown to significantly increase switchgrass yields during the first 3 years after seeding. The control with no fertilizer and light mulch treatment yielded much lower biomass than the other treatments. Fertilizing at $34 \mathrm{~kg} \mathrm{~N}-\mathrm{P}_{2} \mathrm{O}_{5}-\mathrm{K}_{2} \mathrm{O}$ ha ${ }^{-1}$ increased yields by threefold, while fertilizing at $68 \mathrm{~kg} \mathrm{~N}-\mathrm{P}_{2} \mathrm{O}_{5}-\mathrm{K}_{2} \mathrm{O} \mathrm{ha}^{-1}$ increased yields more than sixfold. The heavier mulch treatment in this study had little effect on yield. These experiments were conducted without annual biomass removal, and future research must address nutrient removal and fertilizer inputs required for switchgrass grown in mine soils under annual harvesting.

Acknowledgments This research was funded by the West Virginia Department of Environmental Protection, the NEWBio Northeast Woody/Warm-season Grass Biomass Consortium, and with funds appropriated under the Hatch Act at West Virginia University. Scientific article from the West Virginia Agricultural and Forestry Experiment Station. The authors thank Rick Herd, Brady Gutta, Paul Ziemkiewicz, Ken Ellison, Scott Schumaker, Rodney Mangold, John McHale, Kenny Daniel, George Thornsbury, Rick Adams, Terry Potter, Kermit Fincham, David McMichael, and Marcus McCartney for help with project development, site access, and analysis during the study. 
Open Access This article is distributed under the terms of the Creative Commons Attribution 4.0 International License (http:// creativecommons.org/licenses/by/4.0/), which permits unrestricted use, distribution, and reproduction in any medium, provided you give appropriate credit to the original author(s) and the source, provide a link to the Creative Commons license, and indicate if changes were made.

\section{References}

1. Adler PR, Sanderson MA, Boateng AA, Weimer PJ, Jung HE (2006) Biomass yield and biofuel quality of switchgrass harvested in fall or spring. Agron J 98:1518-1525

2. Anderson EK, Parrish AS, Voigt TB, Owens VN, Hong CH, Lee DK (2013) Nitrogen fertility and harvest management of switchgrass for sustainable bioenergy feedstock production in Illinois. Ind Crop Prod 48:19-27

3. Bendfeldt ES, Burger JA, Daniels WL (2001) Quality of amended mine soils after sixteen years. Soil Sci Soc Am J 65:1736-1744

4. Casler MD, Vogel KP (2014) Selection for biomass yield in upland, lowland, and hybrid switchgrass. Crop Sci 54:626-636

5. Fike JH, Parrish DJ, Wolf DD, Balsako JA, Green JT, Rasnake M et al (2006) Switchgrass production for the upper southeastern USA: Influence of cultivar and cutting frequency on biomass yields. Biomass Bioenergy 30:207-213

6. Gelfand I, Sahajpal R, Zhang X, Izaurralde RC, Gross KL, Robertson GP (2013) Sustainable bioenergy production from marginal lands in the US Midwest. Nature 493:514-517

7. Hong CO, Owens VN, Bransby D, Farris R, Fike J, Heaton E, Kim S, Mayton H, Mitchell R, Viands D (2014) Switchgrass response to nitrogen fertilizer across diverse environments in the USA: a regional feedstock partnership report. Bioenergy Res 7:777-788

8. Kering KM, Biermacher JT, Butler TJ, Mosali J, Guretzky JA (2012) Biomass yield and nutrient responses of switchgrass to phosphorus application. Bioenergy Res 5:71-78

9. Knoll JE, Anderson WF, Strickland TC, Hubbard RK, Malik R (2011) Low-input production of biomass from perennial grasses in the coastal plain of Georgia, USA. Bioenergy Res 5:206-214

10. Lemus R, Brummer EC, Moore KJ (2002) Biomass yield and quality of 20 switchgrass populations in southern Iowa, USA. Biomass Bioenergy 23:433-442

11. Marra M, Keene T, Skousen J, Griggs T (2013) Switchgrass yield on reclaimed surface mines for bioenergy production. J Environ Qual 42:696-703

12. Mitchell R, Vogel KP, Sarath G (2008) Managing and enhancing switchgrass as a bioenergy feedstock. Biofuels Bioprod Biorefin 2: 530-539

13. Muir JP, Sanderson MA, Ocumpaugh WR, Jones RM, Reed RL (2001) Biomass production of 'Alamo' switchgrass in response to nitrogen, phosphorus, and row spacing. Agron J 93:896-901

14. Owens VN, Viands DR, Mayton HS, Fike JH, Farris H, Heaton E, Bransby DI, Hong CO (2013) Nitrogen use in switchgrass grown for bioenergy across the USA. Bioenerg Res 58:286-293

15. Parrish D, Casler MD, Monti A (2012) The evolution of switchgrass as an energy crop. In: Monti A (ed) Switchgrass: a valuable biomass crop for energy. Springer-Verlag, London, pp 1-28
16. Parrish DJ, Fike JH (2005) The biology and agronomy of switchgrass for biofuels. Crit Rev Plant Sci 24:423-459

17. Schmer MR, Vogel KP, Mitchell RB, Perrin PK (2008) Net energy of cellulosic ethanol from switchgrass. Proc Natl Acad Sci 105: 464-469

18. Shapiro SS, Wilk MB (1965) An analysis of variance test for normality (complete samples). Biometrika 52:591-611

19. Shrestha RK, Lal R (2011) Changes in physical and chemical properties of soil after surface mining and reclamation. Geoderma 161: 168-176

20. Skousen J, Emerson P (2010) Release of nutrients from brown and gray sandstone soil substitutes in southern West Virginia. In: Proceedings, 2010 National Meeting of the American Society of Mining and Reclamation, Pittsburgh, PA, June 5-11, 2010. ASMR, Lexington, KY, pp 1135-1143

21. Skousen JG, Venable CL (2008) Establishing native plants on newly-constructed and older-reclaimed sites along West Virginia highways. Land Degrad Dev 19:388-396

22. Skousen J, Zipper C (2014) Post-mining policies and practices in the Eastern USA Coal Region. Intl J Coal Sci Technol 1:135-151

23. Statistical Analysis System (2011) SAS/STAT systems for windows v.9.3. SAS Institute, Cary

24. Stout WL, Jung GA (1995) Biomass and nitrogen accumulation inswitchgrass: effects of soil and environment. Agron J 87:663-669

25. Thomason WE, Raun WR, Johnson GV, Taliaferro CM, Freeman KW, Wynn KJ, Mullen RW (2004) Switchgrass response to harvestfrequency and time and rate of applied nitrogen. J Plant Nutr 27:1199-1226

26. US Environmental Protection Agency (2005) Mountaintop Mining/ Valley Fills in Appalachia Final Programmatic Environmental Impact Statement. EPA Region 3. Philadelphia, PA. EPA 903-R-05002

27. Vogel KP, Brejda JJ, Walters DK, Buxton DR (2002) Switchgrass biomass production in the Midwest USA: Harvest and Nitrogen Management. Agron J 94:413-420

28. West Virginia Department of Environmental Protection (2002) West Virginia Surface Mining Reclamation Regulations (July 15, 2002). (http://www.dep.wv.gov/dmr/codes). §38-2-9. Revegetation

29. Wolf A, Beegle B (1995) Recommended soil tests for macronutrients: Phosphorus, Potassium, Calcium and Magnesium. In: Sims: JT, Wolf AM (eds) Recommended soil testing procedures for the Northeastern United States. Northeastern Regional Pub. No. 493 (2nd edition). Agricultural Experiment Station Univ. of Delaware, Newark, pp 30-38

30. Wright L, Turhollow A (2010) Switchgrass selection as a "model" bioenergy crop: a history of the process. Biomass Bioenergy 34 851-868

31. Wullschleger SD, Davis EB, Borsuk ME, Gunderson CA, Lynd LR (2010) Biomass production in switchgrass across the United States: Database description and determinants of yield. Agron J 102:1158-1168

32. Zegada-Lizarazu W, Wullschleger SD, Nair SS, Monti A (2012) Crop Physiology. In: Monti A (ed) Switchgrass: a valuable biomass crop for energy. Springer-Verlag, London, pp 56-86

33. Zhang Y, Zalapa J, Jakubowski AR, Price DL, Acharya A, Wei Y, Brummer EC, Kaeppler SM, Casler MD (2011) Natural hybrids and gene flow between upland and lowland switchgrass. Crop Sci 51: 2626-2641 